ガラス質火山砕屏物からの微粒シラスバルーンの合成

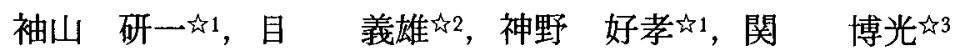

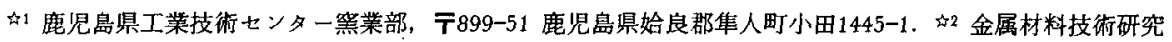

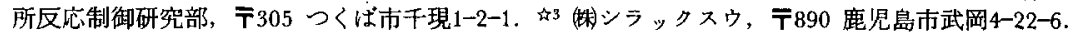

\title{
Preparation of Fine Shirasuballoons from Vitric Volcaniclastic Materials
}

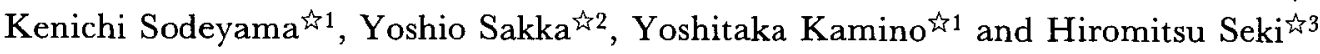 \\ (1) Kagoshima Prefectural Institute of Industrial Technology, 1445-1 Oda Hayato-cho Aira-gun, Kagoshima \\ 899-51. National Research Institute for Metals, 1-2-1 Sengen, Tsukuba 305. 하 Silax Co., Ltd., 4-22-6 \\ Takeoka, Kagoshima 890.
}

Reçeived February 23, 1995

\section{SYNOPSIS}

Finer hollow microballoon is expected to improve the chemical and physical properties of conventional Shirasuballoon, glassy balloon and expanded perlite. It is shown that fine microballoons of particle sizes under $20 \mu \mathrm{m}$ and bulk specific volume above $2 \mathrm{~cm} 3 / \mathrm{g}$ are desired by summarizing those of the conventional Shirasuballoons and glassy balloons. Fine Shirasuballoons are prepared from five kinds of vitric volcaniclastic materials named as Shirasu (or Hakudo); ShinjoShirasu, Kakuto-Shirasu, Yoshida-Shirasu, Nakano-Hakudo and Biei-Hakudo. The five kinds of vitric volcaniclastic materials are milled and expanded using a fluidized bed furnace. Fine Shirasuballoons within the above regions are successfully prepared except Shinjo-Shirasu by choosing appropriate heating conditions, which are different among the milled powders. Preparation conditions and some properties of fine Shirasuballoons are presented.

KEY WORDS

microballoon, Shirasu, whiteness, water content, fluidized bed furnace.

\section{1 緒 言}

真珠岩などのガラス質火山岩を焼成発泡させたも のをパーライト（米国ではExpanded perlite）と呼 び, 主要生産国はギリシャ, 棟，トルコ，米国で， 世界20カ国で140万トン（1992年）生産されている. パーライトは，断熱性と防音性に優れ, 耐火性で超 軽量の資材として, 天井タイル，パイプ絶緑体など に，またろ過助剤，園芸用などに利用されている”。 一方, シラスなどのガラス質火山砕屑物を焼成発泡 させたものは, シラスバルーンと呼ばれ2’九州工業技
術研究所で開発されて以来, 1992年には国内 6 社で 約 1 万 2 千トン生産するまでになっている゙?. シラス バルーンもパーライトと同様な用途の他, 塗料, 紙 粘土などにも用いられている゙2。

鹿児島県工業技術センターでは，シラスバルーン の高付加価值化を目指して，1992年からシラスバル ーン製造メーカーと共同で微粒化に取り組んできだ -6). その結果, カサ比体積 (タップ允填) $2 \mathrm{~cm}^{3} / \mathrm{g}$ 以 上, 平均粒径 $20 \mu \mathrm{m}$ 以下の微粒シラスバルーンを製 造することに成功した，本論文では，微粒シラスバ 
ルーンの合成に関する第 1 報として，市眅のバルー ンの評価を行い 望まれている微粒バルーンの粒径、 カサ比体積の範囲を提示した. ついで，原料粉調製 法，焼成発泡法について記述し，合成した微粒シラ スバルーンの物性を示した.

\section{2 実硂}

2. 1 原料

2. 1.1 分布状況および地質

出発原料として，Fig. 1 に示した産地のガラス質 火山砕屑物を用いた，新城シラスは火砕流一次堆皘 物で、他は、流水などで再移動堆積した物である。

新城シラスは $3 \mathrm{~mm}$ 以下の分級品（清新産業（株））， 加久藤シラスは $75 \mu \mathrm{m} \sim 600 \mu \mathrm{m}$ の分級品（清新産業

（株）），吉田シラスは原鉱（柏原産業），中野白 土は原鉱（丸中白土（株）），美瑛白土は原鉱（美 瑛白土工業（株））を用いた，粉砕には，衝突板式

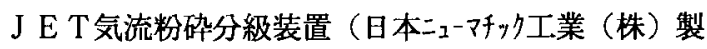
IDS-2型）を用いて，平均粒径 $20 \mu \mathrm{m}$ 以下の原料粉体 を得た，ガラス質以外の夾雑物を除去するために必 要に応じて, 粉砕前に誘導式磁選装置（カネテック

（株）製K10-31M型）を，粉砕前後に遠心風力式気流 分級装置（安川商事 (株) 製YACA-132HL型）を用い た.

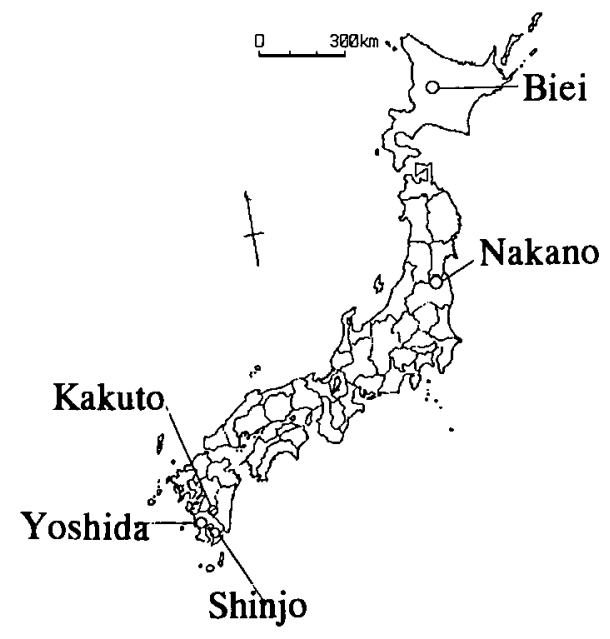

Fig. 1 Distribution map of the vitric volcaniclastic materials used in this experiment.

\section{2 焼成試検}

北開試式砂媒体流動炉を用いて，原料粉体の焼成 発泡試験を行った. Fig. 2 に砂媒体流動炉の全体構 造を示す．流動層部分は，高温度に予熱されたけい 砂により，下方から供給されるプロパンガスが穴あ きの分散板上で着火燃焼し，その火炎で連続的に高 温の熱媒体流動状態が保持される構造になっている.

この流動層の温度は，プロパンガスと空気の混合比 上供給量によって変化し，流動炉中心部にセットさ れた熱電対の温度を制御盤に取り込み，PID制御によ ってプロパンガスと空気の混合比を電磁バルブで自 動制御している.この自動制御によって，最高焼成 温度が $800^{\circ} \mathrm{C} \sim 1200^{\circ} \mathrm{C}$ まで可変でき，その設定温度 差土 $5{ }^{\circ} \mathrm{C}$ 以内を可能としている. 原料粉体は, プロ パンガスと空気の混合ガスと共に炉の下部から供給 し, 流動層部分で 1 秒以内で高温まで急速に加熱さ れる. そこで発泡して軽量化した原料粉体は，燃焼 ガスと共に流動層から放出され，冷却しながらサイ クロンに送られ，連続的に補集される.

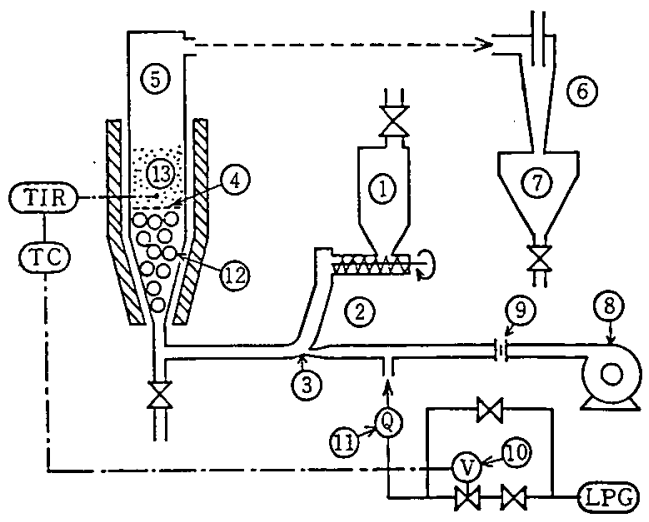
1. raw material hopper
2. screw-feeder
3. mixer
4. dispersion plate
5. furnace
6. cyclone
7. products hopper
8. blower
9. orifice meter
10. electromagnetic valve
11. LPG flow meter
12. ceramic balls
13. heating medium

Fig. 2 Apparatus of fluidized bed furnace.

\section{3 物性測定}

粉体特性としては, 化学分析, 熱重量分析, 粒度 分析, カサ比体積 (タップ充填), 白色度 水浮揚 
率，ガラス含有量の测定を行った．熱重量分析は， 熱天秤 (理学電機 (株) 製TAS-200型) を用い，昇温 速度 $20^{\circ} \mathrm{C} / \min$ 条件で大気中にて行った. 粒度分析 は, レーザー回折式粒度分析䒾置 (Sympatec社製HEL OS-RODOS）を用い，湿式で超音波分散後，体皘基準 頻度分布, 平均粒径を測定した. 力サ比体皘 $\left(\mathrm{cm}^{3} / \mathrm{g}\right)$ は, ホソカワミクロン (株) 製パウダーテスター PT -E型と，付属の金属製カップ（内容積 $100 \mathrm{~cm}^{3}$ ) を用 いて, タップ高さ $20 \mathrm{~mm}$, タップ速度 60 回/min, 夕 ップ回数200回の条件で測定した，水浮揚率は，重液 分離管に水を溶媒として用い，1000rpmで30分間遠心 回転して浮揚物分離し，ガラスフィルターでろ過， 乾燥したのち，秤量して水浮揚率を計算した．ガラ 又含有量は, 比重2.40臭化亜鉛水溶液に上り浮沈分 離し，その浮揚物をガラス分として全体に対する重 量割合として求めた。

\section{3 結 果 およひ 考 察}

3. 1 市眅シラスバルーン, ガラスバルーンの物性 市販シラスバルーンと合成ガラスから製造された 市販ガラスバルーンについて, カサ比体積, 平均粒 径、白色度の測定を行った. 市販のシラスバルーン

（A〜Fまでの 6 社の製品）は，選鉱処理して結晶 質を除去し，粒度調整したのち， $1000^{\circ} \mathrm{C}$ 前後で 1 分 以内の整時間焼成で作製されている72. 烧成师として, ロータリーキルン, 流動焙焼炉, シャフトキルンな どが用いられていだ．本実験で用いた北開攻少媒体 炉では 1 秒以内に高温まで急速加熱されるのに比べ, 昇温速度は遅い一一方, 合成品のガラスバレーンは, 種類も多く, 化学組成, 製造法も異なるが, ここで は、良く用いられているウケイ酸ガラス組成)のガ ラスバルーン（G〜I までの 3 社の製品）について 測定した. ガラスバルーンの製造は，液滴法および スプレドライ法が採用されている92。

Fig. 3，4に、市販シラスバルーンおよびガラス バルーンのうち比較的小さな粒径の製品について, カサ比体積と平均粒径を測定した結果を示す.ガラ スバルーンは, 粒度が $40 \mu \mathrm{m}$ 前後に製品の偏りがみ られ，シラスバルーンの方が比較的細かい粒径まで 製品がある. しかし, 平均粒径 $20 \mu \mathrm{m}$ 以下で, カサ 比体積 $2\left(\mathrm{~cm}^{3} / \mathrm{g}\right)$ より大きな製品が無いことが分か る.
一般に, シラスバルーンは, ガラスバルーンより 白色度が低く，その範囲は71.7〜82.8 報告されて (る ${ }^{(5)}$. 本実験結果でも，ガラスバルーンの白色度 が97前後であるのに対し，シラスバルーンのそれは， 80前後と低い値であった。

シラスバルーンの最大の利点は, ガラスバルーン に比へ，洒格が約 $1 / 10$ と安いことである.そこで， 平均粒径 $20 \mu \mathrm{m}$ 以下で, カサ比体皘 $2\left(\mathrm{~cm}^{3} / \mathrm{g}\right)$ より 大きく，白色度も高い微粒シラスバルーンを作製す ることを目標とした。

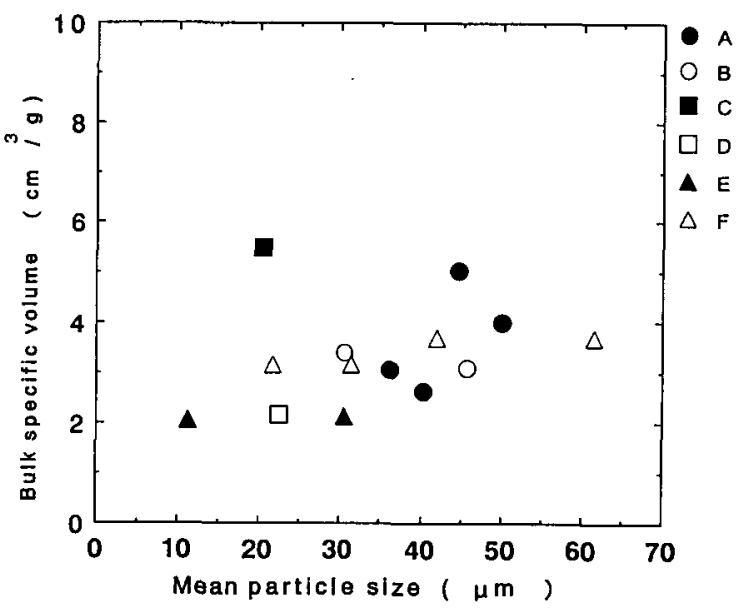

Fig. 3 Relationship between bulk specific volume and mean particle size of conventional Shirasuballoons.

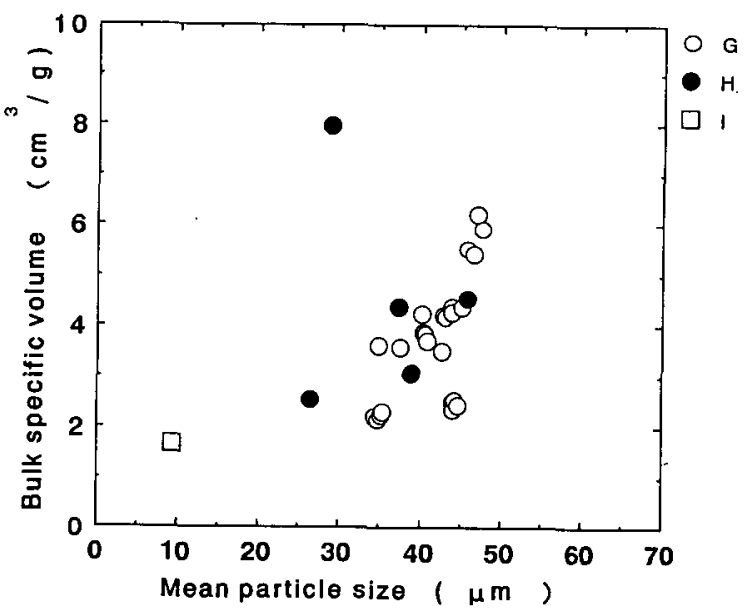

Fig. 4 Relationship between bulk specific volume and mean particle size of conventional glassy balloons. 


\section{2 原料粉体の物性}

Fig. 5に原料粉を選鉱、粉砕後のX線回折図を示 す．図より，主成分はガラス構造をしており，僅か に石英，長石の結晶質鉱物を含んでいることが分か る. Table 1 に原料粉体のガラス含有量を示す. 火 䂶流堆積物の新城シラスはガラス含有量が最も少な く，他は火山砕屑物が流水などにより再移動し堆皘 したもので，原鉱の状態でガラス含有量が $90 \%$ 上上 含まれている，選鉱，粉砕後は，いずれも高いガラ ス含有量を示している.

各試料の化学分析值をTable 2 に示す. 化学分析 值は，いずれも高 $\mathrm{SiO}_{2}$ 質で酸性の流效岩質であり，黒 曜岩，真珠岩，松脂岩のガラ瓆火山岩と類似のも

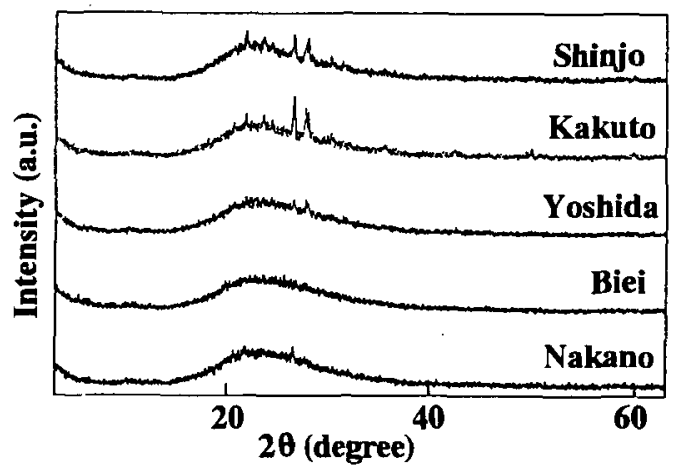

Fig. 5 X-ray diffraction patterns of the milled powders.

Table 1 Glassy part content.

\begin{tabular}{lll}
\hline & raw powder & milled powder \\
\hline Shinjo & 83.2 (mass\%) & 87.3 (mass\%) \\
Kakuto & 92.9 & 93.8 \\
Yoshida & 95.1 & 96.9 \\
Nakano & 96.3 & 97.7 \\
Biei & 95.5 & 98.4 \\
\hline
\end{tabular}

のと言える"'．ガラス質火山岩の分類は，外観で見 分けがつかない場合があり，加熱脱水量 $\left(\mathrm{H}_{2} \mathrm{O} \pm\right)$ も産地で異なる。岡野によれば黒曜岩 $\mathrm{H}_{2} \mathrm{O} \pm<2 \%$, 真珠岩 $\mathrm{H}_{2} \mathrm{O} \pm 2 \% \sim 5 \%$ 松脂岩 $\mathrm{H}_{2} \mathrm{O} \pm>5 \%$ 之 分類している ${ }^{12)} . \mathrm{H}_{2} \mathrm{O} \pm\left(1000^{\circ} \mathrm{C}, 2 \mathrm{~h}\right.$ 保持での加 熱脱水量）の量から言えば，新城シラス、加久藤シ ラスが真珠岩, 吉田シラス, 中野白土, 美䒨白土が 松脂岩の分類になる.

ガラス質火山岩を熱処理して発泡体を得る場合の 発泡源は，その中に含まれている水分であること， その加熱脱水は粒子婊面及び内部に存在する $\mathrm{H}_{2} \mathrm{O}$ 分 子と $\mathrm{OH}$ 基に由来し， $\mathrm{H}_{2} \mathrm{O}$ 分子は， $\mathrm{OH}$ 基より低温 で粒子外へ拡散することが知られている13)。我々は， 本研究に用いたガラス質火山砕屏物を高真空中で定 速加熱し，脱離ガスを質量分析計で分析した結果， ほとんどが水であることを明柿にしだ、1.

Fig. 6に大気中での熱分析の結果を示す．いずれ も， $300^{\circ} \mathrm{C} \sim 400^{\circ} \mathrm{C}$ 間で最も脱水量が多く，全脱水 量及び脱水曲線に差異が認められる。 $400^{\circ} \mathrm{C}$ 以下につ

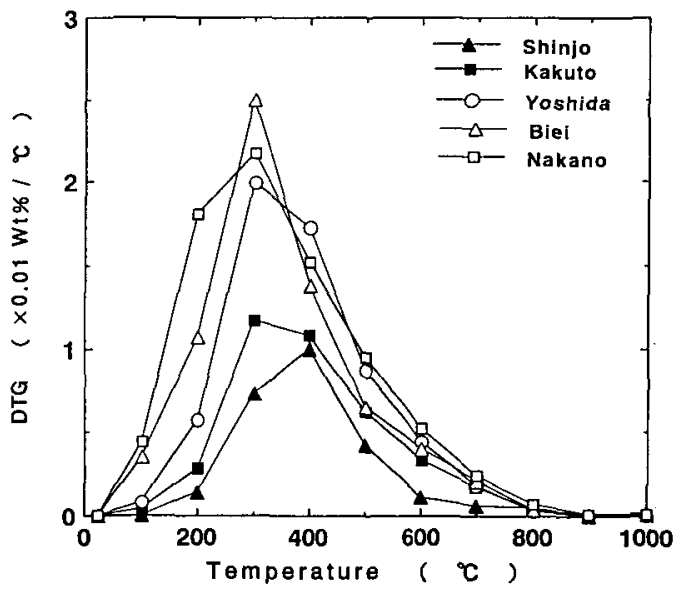

Fig. 6 DTG curves of the milled powders.

Table 2 Chemical composition of the milled powders (mass $\%$ ).

\begin{tabular}{lcccccccccc}
\hline & $\mathrm{SiO}_{2}$ & $\mathrm{Al}_{2} \mathrm{O}_{3}$ & $\mathrm{~K}_{2} \mathrm{O}$ & $\mathrm{Na}_{2} \mathrm{O}$ & $\mathrm{CaO}$ & $\mathrm{Fe}_{2} \mathrm{O}_{3}$ & $\mathrm{MgO}$ & $\mathrm{TiO}_{2}$ & Ig. loss & Total \\
\hline Shinjo & 72.03 & 12.60 & 3.53 & 3.36 & 1.41 & 1.47 & 0.19 & 0.18 & 2.79 & 97.56 \\
Kakuto & 71.87 & 12.48 & 3.39 & 3.59 & 1.32 & 1.64 & 0.22 & 0.15 & 3.98 & 98.64 \\
Yoshida & 69.72 & 12.60 & 3.36 & 2.89 & 1.59 & 1.56 & 0.29 & 0.28 & 5.85 & 98.14 \\
Nakano & 71.34 & 11.82 & 3.14 & 2.52 & 1.04 & 1.72 & 0.08 & 0.06 & 6.98 & 98.70 \\
Biei & 69.06 & 13.05 & 4.37 & 1.64 & 1.36 & 1.60 & 0.34 & 0.15 & 7.18 & 98.75 \\
\hline
\end{tabular}


いて比較すると, 新城シラス, 加久藤シラスの脱水 量は、他の 3 種類のに比べて少ない.これは、前述 した真珠岩, 松脂岩の分類に対応している. 脱水量 のピーク以上の温度においては, 新城シラスが $600^{\circ} \mathrm{C}$ までにほぼ脱水が終了しているが, 他の 4 種類は800 ${ }^{\circ} \mathrm{C}$ 以上まで徐々に脱水量が少なくなる傾向が認めら れる. この結果は, 粒子表面及び内部に存在する水 の存在量に関係するが, 後述するように発泡特性に 影響する.

3. 3 微粒シラスバルーンの合成と物性

Fig. 7 (a) 〜 (e ) は, 砂媒体流動炉により10 $20^{\circ} \mathrm{C}$ 焼成前後の粒度分布を示している. いずれの試 料においても，焼成により粒度分布が大きい方へシ フトしているのが分かる. その平均粒径から粒子の 膨張倍率を比較したのがTable 3 で, 焼成後の值を 焼成前の値で割って算出した. 一例として, Photo 1 に吉田シラスの焼成前後のSEM写真を示す.

新城シラスは, 焼成温度が高くなるほどカサ比体 積と平均粒径が大きくなる傾向を示したが, 焼成温 度 $1100^{\circ} \mathrm{C}$ 以上では流動炉内で融着が生じる温度域で あるため, それ以上では実験を行わなかった. 他の 試料は、カサ比体積之平均粒攂二極大值力認められ, 加久藤シラスでは約 $1070^{\circ} \mathrm{C}$, 吉田シラス、中野白土

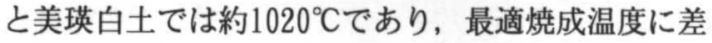
が認められた.

焼成発泡実験で得られた微粒シラスバルーンのカ サ比体積と粒径の最大值と最小值を, 試料ごとに囲

Table 3 Expansion parameters of the powders.

\begin{tabular}{lccc}
\hline & $\begin{array}{c}\text { mean particle size }(\mu \mathrm{m}) \\
\text { raw powder } \\
(\mu \mathrm{m})\end{array}$ & $\begin{array}{c}\text { products } \\
(\mu \mathrm{m})\end{array}$ & $\begin{array}{c}\text { coefficient of } \\
\text { expansion }\end{array}$ \\
\hline Shinjo & 8.4 & $10.1 \sim 11.4$ & $1.2 \sim 1.4$ \\
Kakuto & 8.9 & $11.7 \sim 13.8$ & $1.3 \sim 1.6$ \\
Yoshida & 8.1 & $12.2 \sim 12.8$ & $1.5 \sim 1.6$ \\
Nakano & 8.5 & $11.5 \sim 12.8$ & $1.4 \sim 1.5$ \\
Biei & 8.1 & $9.5 \sim 11.7$ & $1.2 \sim 1.4$ \\
\hline
\end{tabular}



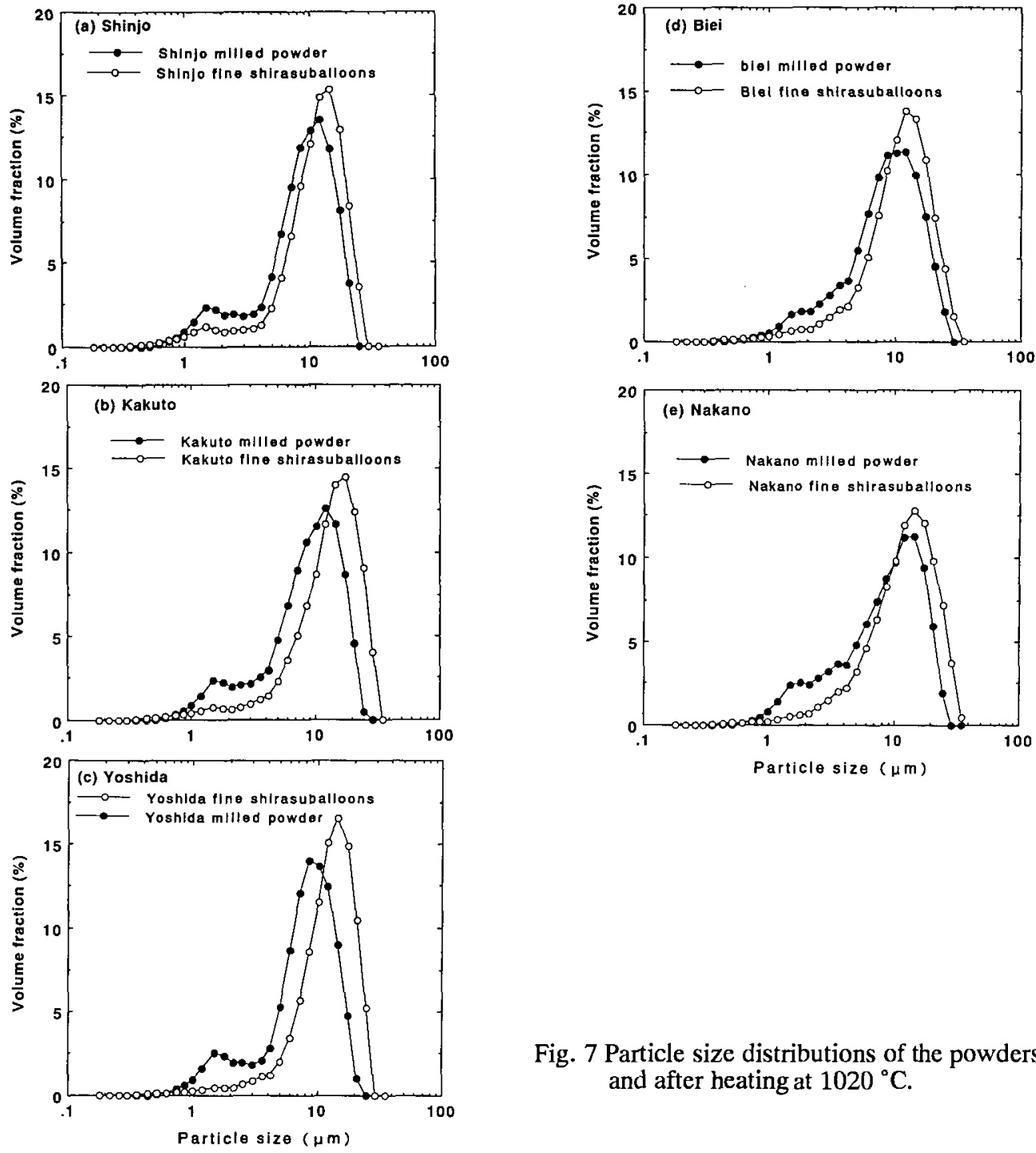

Fig. 7 Particle size distributions of the powders before and after heating at $1020^{\circ} \mathrm{C}$.

Table 4 Characteristics of the fine Shirasuballoons.

\begin{tabular}{|c|c|c|c|c|c|}
\hline & Shinjo & Kakuto & Yoshida & Nakano & Biei \\
\hline $\begin{array}{c}\text { mean particle size } \\
\left(\begin{array}{c}\mu \mathrm{m}\end{array}\right)\end{array}$ & $10.1 \sim 11.4$ & $11.7 \sim 13.8$ & $12.2 \sim 12.8$ & $11.5 \sim 12.8$ & $9.5 \sim 11.7$ \\
\hline bulk $\underset{\left(\mathrm{cm}^{3} / \mathrm{g}\right)}{\operatorname{specific}}$ volume & 1. $09 \sim 1.42$ & $1.72 \sim 2.28$ & 3. $31 \sim 3.84$ & 2. $16 \sim 2.73$ & 2. $50 \sim 2.80$ \\
\hline $\begin{array}{c}\text { bulk dens i ty } \\
\left(\mathrm{g} / \mathrm{cm}^{3}\right)\end{array}$ & $0.92 \sim 0.70$ & $0.54 \sim 0.44$ & $0.30 \sim 0.26$ & $0.46 \sim 0.37$ & $0.40 \sim 0.36$ \\
\hline $\begin{array}{l}\text { yield of floating } \\
\text { particles (massy) }\end{array}$ & 5.8 & 8. 2 & 16.0 & 10.1 & 11.0 \\
\hline Whiteness & $84.6 \sim 85.9$ & 83. $6 \sim 84.4$ & $90.0 \sim 91.8$ & $85.4 \sim 88.0$ & $86.0 \sim 87.9$ \\
\hline $\begin{array}{l}\text { Ig. loss } \\
\text { (mass } \%)\end{array}$ & 0.98 & 1. 54 & 1. 44 & 1.48 & 0.89 \\
\hline
\end{tabular}




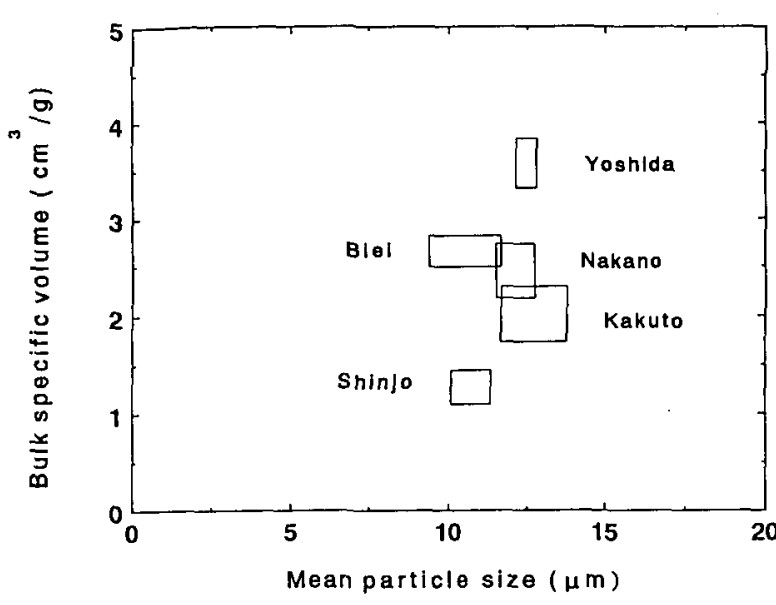

Fig. 8 Relationship between bulk specific volume and mean particle size of the fine Shirasuballoons produced.

出を抑止する働きもする)が破壊されるため ${ }^{102}$ ，粉砕 したままの原料から微粒バルーンの合成は困難とされて いた，木村らは，水熱処理を行うことにより，風化表面 層を形成させるとともに，水含有量を增加させることで， 微粒バルーンを合成した ${ }^{0)}$ 。本研究では，加熱速度を 木村らの場合より60倍程度上げることにより，一定量以 上の水分を含有しているガラス質火山破首物に対しては, 微粉碎した試料でも発泡が可能であることを示している. Table 4には，水浮揚物でない焼成しただけの微粒 シラスバルーンの平均粒径, カサ比体積, 力サ密度 の最大值, 最小值の範囲と, 最も大きな力サ比体積 を示した微粒シラスバルーンの水浮揚率, 白色度, 加熱脱水量 $\left(\mathrm{H}_{2} \mathrm{O}\right.$ 土) を示した. 白色度は，ハン夕 一方式による白色度 (W) で，次式に上り算出した ${ }^{16)}$. $\mathrm{W}=100-\left\{\left(\begin{array}{lll}1 & 0 & 0\end{array}-\mathrm{L}\right)^{2}+\mathrm{a}^{2}+\mathrm{b}^{2}\right\}^{1 / 2}$ ここで，Lはハンタ一の色差式における明度指数, a , bは，ハンタ一の色差式におけるクロティクネ ス指数である.

最も白色度が高いものは，吉田シラスから製造した 白色度91.8で，原料粉体の白色度が86.6であり，焼 成発泡によって白色度から. 2ポイント向上した また 微粒シラスバルーンのカサ比体積が大きいものほど 高い白色度を示した. これは良く発泡するものほど 発泡体内部に空間が生じることと，ガラス殸が薄く なることから光が乱反射して白色度が向上すること
などによると考えられる：このように，当初の目標 である白色度の高い微粒シラスバルーンも合成でき ることが分かった．微粒シラスバルーンの白色度は， 原料粉体中の鉄分の含有量にも依存する ${ }^{14)}$. 従って, 原料粉体中の鉄分の含有量を磁力選鉱機などを用い て除去すれば、今後さらに白色度を向上させること 屯可能と考えられる.

\section{4. 結 言}

5 種類のガラス質火山砕首物（新城シラス，加久 藤シラス, 吉田シラス, 中野白土, 美瑛白土）の粉 砕物を北開試式砂媒体炉を用いて、急速焼成発泡さ せ，微粒シラスバルーンの合成を行い，以下の結果 を得た。

（1）使用したガラス質火山砕屑物は，ガラス構造 をしており，化学組成でも高 $\mathrm{O}_{2}$ 質で酸性の流就岩質 で，岡野によるガラス質火山岩の分類によれば，新 城シラス, 加久藤シラスは真珠岩, 吉田シラス, 中 野白土，美瑛白十は松脂岩に類以なものと言える。

（2）熱分析の結果から，原料粉体は $300^{\circ} \mathrm{C} \sim 400^{\circ} \mathrm{C}$ の間で最も脱水量が多く，この温度以上では，新城 シラスが他の試料に比べて脱水量が少なく，発泡特 性も悪かった. 水分含有量が発泡特性に密接に関係 していることを示した。

（3）砂媒体流動炉によるガラス質火山砕屑物の粉 砕物の烧成発泡の最適な条件は，出発原料によって 異なった。吉田シラス，美瑛白土，中野白土，加久 藤シラスから, 目標の平均粒径 $20 \mu \mathrm{m}$ 以下, カサ比 体積 $2 \mathrm{~cm}^{3} / \mathrm{g}$ り大きい微粒シラスバルーンが合成で きた。 また、吉田シラスから作製した微粒シラスバ ルーンは, 白色度も91.8ट高し值であった

\section{謝 辞}

本研究の一部は，著者の 1 人（袖山）による中小 企業技術指導員養成課程での実習として行われたも のてある。本研究を遂行するに当たり，ご協力頂い た関係各位に感謝します。また，原料のガラス質火 山砕居物を提供していただいた清新産業（株），柏 原産業，丸中白土（株），美瑛白土工業（株）に対 し厚く感謝の意を表します。 


\section{文 献}

1) P. Bolen:Bull. Am. Ceram. Soc. , 73 (1994) 117.

8)フィラー研究会編：フィラー活用辞典（1994）119.

2）木村邦夫，陣内和彦，諌山幸夫:窯業協会誌，80

9)フィラー研究会編 : 機能性フィラーの最新技術 (1972)84.

3）(財）日本産業技術振興協会:「シラスバルーン の市場動向調查報告書」(1994)3-51にその後の 調查を追加 (1990)163.

10）木村邦夫, 陣内和彦，立山博:日本セラミックス 協会誌, 99 (1991)1240.

11）木村邦夫，陣内和彦:九州工業技術試験所報告, 16 (1976) 870 .

4）袖山研一, 神野好孝: 有田国際ファインセラミッ クス・シンポジウム1992年講演録,（1992） 202.

12）浜野健也：窐業協会誌, 73 (1965) 64.

5) 袖山研一:平成 5 年度VSI (火山珪酸塩工業) 研 究講演会要旨, (1994) 13.

13）谷口宏充:岩石鉱物鉱床学会誌, 67 (1972）291.

14）袖山研一, 目 義雄:未発表データ

6）鹿児島県工業技術七ター：「地域技術おこし事業研 究成果報告書」，(1993)45.

15）立山 博, 木村邦夫, 陣内和彦, 恒松絹江：粘土科 学、22(1982)1.

7)化学工学協会関東支部編 : 特殊粉体技術 (1975) 119.

16）日本セラミックス協会編:セラミックス匹学ハン ドブック, (1989)1418. 